International JOURNAL OF MULTidisciplinary RESEARCH AND ANALysis

ISSN(print): 2643-9840, ISSN(online): 2643-9875

Volume 05 Issue 01 January 2022

DOI: 10.47191/ijmra/v5-i1-11, Impact Factor: 6.072

Page No.- 77-82

\title{
The Impact of Ancient Chinese on Baihua Language
}

\author{
Akram Karimov ${ }^{1}$ Feruza Khasanova ${ }^{2}$ \\ ${ }^{1}$ Candidate of Philological Sciences, ProfessorTashkent State University of Oriental StudiesTashkent, Uzbekistan \\ ${ }^{2} \mathrm{PhD}$, Senior Lecturer Tashkent State University of Oriental Studies Tashkent, Uzbekistan
}

ABSTRACT: This article analyzes the influence of the ancient classical literary language - the Wenyan communication language on the Baihua language. Lexical and grammatical differences are discussed on both fronts of a language. Since the Wenyan language is represented by monosyllabic units, several meanings of a hieroglyph have the property of changing its semantic meaning according to the position of the hieroglyph in the sentence or sentence. It is extremely important to pay attention to this aspect in reading and interpreting ancient texts. The Baihua language, on the other hand, is represented by polysyllabic units, which are much more convenient than the Wenyan language in expressing the semantic meaning of a word. However, the Wenyan language played an important role in the formation of the Baihua language, and to this day some elements of the Wenyan language are also reflected in the Putonghua.

KEY WORDS: Wenyan, Baihua, Putonghua, monosillab, polysillab, "May 4 movement".

\section{INTRODUCTION}

By getting to know Wenyan, it will be possible to read Chinese ancient and classical art monuments in their true form and feel the true value of these sources. Wenyan has always been considered the language that separates Chinese intellectuals and the common people. The reflection of the Chinese language, its description, its internal structure, its features become more obvious to the person who studies Wenyan.

When you read the texts written in Wenyan, you feel the elegance, originality, Chinese traditions, culture, history of the Chinese language. By studying the internal structure of Wenyan, however, a deeper understanding of modern Chinese, the grammatical structure, and some of the puzzles will be solved on their own $[1,54]$.

In the process of studying the Baihua language, we realized that the works written in the Baihua in the ancient and medieval times were poorly studied from a linguistic point of view, and the main reason for this was that the works in Baihua were written "frivolous" way which did not attract the attention of Chinese linguists. However, by the time of the Ming and Qing dynasties (1368-1911), we can acknowledge that Wenyan was abolished by Baihua, and even after the "May 4 movement" of 1919 , it gained its status as a national and state language.

By the end of the Qing Dynasty, the Baihua language had gained prominence. In Baihua, works of art, periodicals began to appear. Famous novels, one of the masterpieces of Chinese literature, were also created in Baihua. In this way, we can clearly see that the Baihua language is modern, able to meet the requirements of the time, understandable to all segments of society. However, the venyan did not disappear completely. Wenyan was still significant for its charm.

Ancient Chinese is the ancestor of "modern Chinese" and is the national language of the Han nation in the pre-May 4 movement, 1919. This language has a common linguistic basis with modern Chinese, and its lexical and grammatical structure are also compatible; but differs greatly from modern Chinese in terms of lexical system and spoken language. Ancient Chinese usually represents an ancient written language, including "wenyan" and "ancient baihua". He combined the features of the languages of earlier periods and developed various linguistic methods of writing, sometimes very complex ideas [1, 54].

By 1962 in China “明清文学语言研究会 Míng Qīng wénxué yǔyán yánjiū huì Ming and Qing Literary Language Research Association" was founded $[2,1]$. The main purpose of the establishment of the association was to study the language of works of art in the baihua, the grammatical features of the Baihua. 


\section{The Impact of Ancient Chinese on Baihua Language}

\section{THE MAIN RESULTS AND FINDINGS}

The results of the research of this association show that although there is a difference in the lexicon of works belonging to the Ming and Qing periods with the works in the early Baihua language, the influence of Wenyan in the works was certainly strong. Especially, we can distinguish two types of personal pronouns in such works “水浒传 Water Margin" and “三国志演义 Romance of the Three Kingdoms". If such pronouns as 我 wǒ $I$, 俺 ăn I, 咱 zan myself, 你 nǐ you, 您 nín You, 恁 nín You representing the meaning of respect (您 nín synonym of the pronoun You), 他 tā he, 它 tā it are characteristic of oral speech, then such pronouns as 某 mǒu I (this pronoun more expressed the meaning of discrimination), 吾 wú I, 汝 rŭ you (in reference to a peer or younger than himself), 君 jūn You (only for people whose career is great), 尔 ěr you we can say that it was mastered from Wenyan and used to enrich the effectiveness of written language.

玄德少时, 与家中诸小儿戏于树下, 吾为天子, 此长朝殿也。其叔父刘德然见玄德发此语, 曰: 汝勿语戏, 灭 吾门。Xuán Dé shăoshí, yǔ jiāzhōng zhū xiăo érxì yú shù xià, wú wéi tiānzĭ, cǐ zhăng cháo diàn yě. Qí shúfù liúdérán jiàn Xuán Dé fā cǐ yŭ, yuē: Rǔ wù yǔ xì, miè wú mén. When Xuan was young he De used to play under the tree with the young children of his family, I am the son of the emperor and also the (master) of this palace. His uncle Liu Deran Xuan De saw him saying this, he said: "don't make fun of me, get out of my door." [3]. In this quoted passage instead of the singular personal pronoun 我 wǒ / is used 吾 wú мен and instead of pronoun 你 nǐ you is used 汝 rŭ you. The use of personal pronouns in this way represents the arrogant tone of speech, i.e. it adds a stronger emotional tone to the speech [2, 4].

Baihua is significant in that is has a large number of two-syllable polysyllabic words. Adverbs also consist of two syllables, a condition which is observed neither in Wenyan nor in Putonghua, i.e., we can see that it is characteristic only of baihua. Such adverbs as 好生 hàoshēng may be the example of for this. This word consists of two syllables 好 hào good and 生 shēng birth; creat which is a compound word consisting of two syllables expressing their meanings. The meaning of the adverb 好生 hàoshēng was used as a function of adverb 很 hen very in a modern Chinese.

咱更不回书，您好生传示朱招讨道 [2,11]。Zán gèng bù huí shū, nín hàoshēng chuán shì Zhū Zhāo tǎo dào. We can analyze the meaning of the words in the sentence:

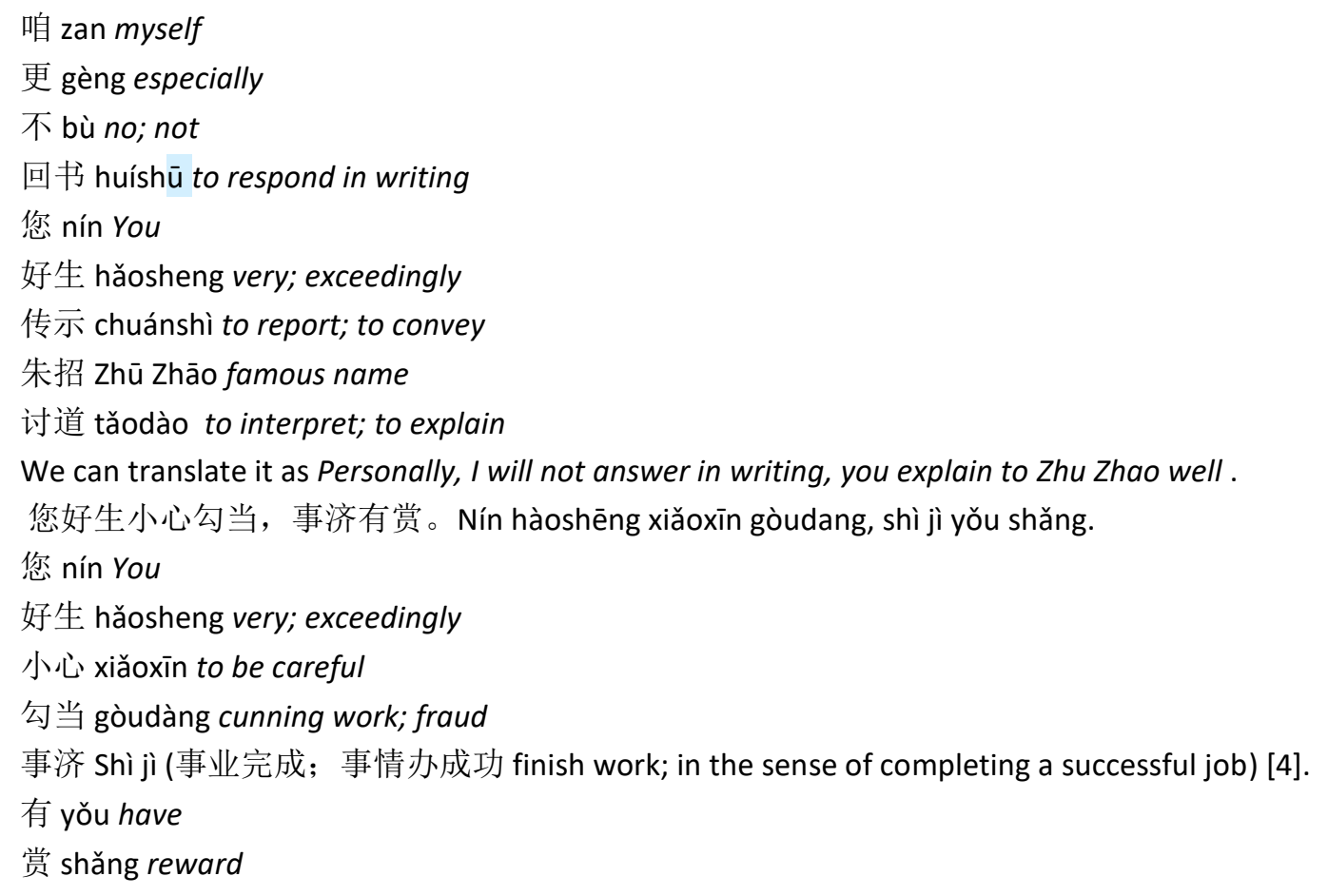

You have committed fraud very carefully, there is a reward when the work is finished.

In the both of above analized sentences 好生 hăosheng the two-syllable degree form was used before the verb, expressing meanings such as “very, exceedingly". However, as noted in the the book “白话语汇研究 Baihua lexicon research" of Xiang Banshun, Jiang Lansheng, Bay Veyguo the the novel “红楼梦 Dream of the Red Chamber" the adver 好生 hăosheng can be seen as a adverb of circumstance in some cases $[2,11]$. But we could not find an example of this. In addition, this form is now found in some dialects as a adver of degree.

In Baihua texts there are many adverbs meaning such as 将次 jiāngcì soon, 将近 jiāngjìn in a short time, 将及 jiāng jí coming soon $[2,230]$.

小弟已差人去了, 将次回也。Xiǎodì yǐ chà rén qùle, jiāng cì huí yě. Someone sent my brother, he will be back soon. 


\section{The Impact of Ancient Chinese on Baihua Language}

The adverb meaning 将近 jiāngjin in a short time may form a compound with quantity word.

自此往来, 将近一月有余。Zì cǐ wănglái, jiāngjìn yī yuè yǒuyú. Since then, it will soon be more than a month.

Unlike Wenyan and Putonghua, the two-syllable adverbs such 又复 yòu fù else (again; another) and 复又 fù yòu else (again; once more) found only in baihua texts represent the recurrence of an action. Both variants of this adverbs have the same meaning.

说毕，复又倒地。Shuō bì, fù yòu dăo dì。He finished talking and fell to the ground again.

又复一刀，就割下头来。Yòu fù yīdāo, jiù gē xiàtou lái. With another knife blow, he cut off his head [2, 187].

Furthermore, the two-syllable adverbs such 且又 qiě yòu and again, 又且 yòu qiě again as well, 况且 kuàngqiě in addition, 且况 qiě kuàng besides which are synonymous with two-syllable adverbs 又复 yòu fù else (again; another) and 复又 fù yòu else (again; once more) are distinguished by the high frequency of occurrence in Baihua texts. The meaning does not change even when the two-syllable adverbs replace the first and second syllables.

吕叔湘 Liu Shusyang suggests that the hieroglyph 又 you is a time adverb meaning "again; both; so, once more; newly", but it also comes in the function of a connective in connected conjunctions [5, 9]. In Wenyan 又 you can be applied alone or along with the hieroglyph 而 er. But in Baihua 又 you occurs in both parts of a connected compound sentence, sometimes when the sentence consists of three parts, it occurs in all three parts, and mean "again; both; and; as well as".

初到那里, 人地又生疏, 钱又不湊手（45）[6]。Chū dào nàlĭ, rén dì yòu shēngshū, qián yòu bù còu shǒu. When I first arrived there, and people were strangers, and the place was alien, and I had no money.

这一碗牛奶喝下去, 又香, 又甜, 又热和 (45)。Zhè yī wăn niúnăi hē xiàqù, yòu xiāng, yòu tián, yòu rè huo. Here is $a$ bowl of milk to drink, both fragrant, sweet and hot.

In these two sentences, the 又 you hieroglyph is equally connected, which is repeated in the second and third parts of the compound sentence, which is unique to the Baikhua language. In Wenyan, the first part of a compound sentence consisting of two parts is usually expressed as 既 ji, and the second part as 又 you or 而又 eryou. Since 又 you is not used repeatedly in Wenyan, we can see that in conjunctions hieroglyphs such as 而 er, 又 you, 且 qiě appear. 吕叔湘 Liu Shuxiang calls the methods used repeatedly in compound sentences and the constructions expressed by these methods parallelisms. Liu Shuxiang goes on to say that in addition to being used in parallel in compound sentences, the adverb 又 you can also have opposite meanings in compound sentences. And he explains this feature with Baihua texts $[5,20]$.

有时闷了, 又盼個姐妹来说些闲话排遣，及至宝钗等来望候，他说不得三五句话，又厌烦了(45)。

Yǒushí mènle, yòu pàn gè jiěmèi lái shuō xiē xiánhuà páiqiǎn, jí zhì Băo Chāi děng lái wàng hòu, tā shuōbudé sānwǔ jù huà, yòu yànfánle.

Sometimes when he was bored, he hoped that one of his sisters would come and visit him, talk to them and spread the dust, but in reality, when Bao Chai or someone else came, he could not speak 3-4 words, he would be annoyed again.

In Baihua the adverb meaning 且 qiě again, as well as, also is not applicable alone, usually the adverbs 而且 érqiě also, 并且 bìngqiě as well as; again, 况且 kuàngqiě as well as; again are used to represent such meaning. In Wenyan single syllable hieroglyph 况 kuàng again; also, in Baihua represents with two syllable like 何况 hékuàng as well as; more; also.

From this it can be concluded that there was an organic connection between the baihua and the wenyan, and that the polysyllabic units were used to express the meaning more precisely by adding the monosyllabic units that had the same meaning in the baihua.

In the process of researching our topic by analizing the adverbs in baihua we have studied the views on the adverbs in I.T. Zograf's article on medieval Chinese grammar titled "Наречия в среднекитайском языке - Adverbs in medieval Chinese" and, in the book of Xiang Banshun, Jiang Lansheng, Bai Weiguo titled “白话语汇研究 Baihua lexicon research”. According to IT Zograf, the morpheme 可 is an adverb and is used in interrogative pronouns and is used in conjunction with interrogative pronouns and reinforces the meaning of interrogation. This adverb is in the middle position between the subject and the predicate group, emphasizing that if there is no possessor in the sentence, then it comes at the beginning of the sentence $[7,56]$.

可怎生恁般厉害 Kě zěn shēng rèn bān lihài? How can this be so great?

In the book “白话语汇研究 Baihua lexicon research” the morpheme 可 is defined as a prefix denoting the interrogative pronoun.

我问他可会写字, 可愿出门 [8]? Wǒ wèn tā kě huì xiězì, kě yuàn chūmén? I asked him if he was literate and would he like to go out?

In this case, we see that the morpheme 可 precedes the predicate and reinforces the meaning of the question. This can be done without the participle putunghuada-morpheme. The content does not change. Thus, we can recognize that the use of 


\section{The Impact of Ancient Chinese on Baihua Language}

this morpheme in the way of the word family was the same in the medieval Baihua language and in the twentieth century Baihua novels. In contrast to Wenyan and Baihua, in the Putunghua the morpheme 可 means"may; to allow; to permit "but is not used to reinforce the meaning of the question, as in Baihua.

Prefixes. In modern Chinese the functions expressed by the prefix 向 xiang ...to; ...towards representing the direction and the prefixe 在 zai ....in representing the place and time, in the baihua texts have the same meaning and are used in place of each other.

\section{The prefixes 向 xiang and 在 zai}

他有个好恶在里。Tā yǒu gè hàowù zài lǐ. He has good and bad (qualities).

As for the semantic meaning of the word 在里 zài lǐ in this sentence, it consists of two morphemes in 在 zài ... and 里 lǐ, which in itself means scope. However, the word 向里 xiàng lĭ, the two morphemes 向 xiàng ... ga and 里 lǐ are exactly the same in meaning with a compound word composed of larn. Therefore, the sentence 他有个好恶向里。Tā yǒu gè hàowù xiàng lǐ can also be interpreted as He include (into) good and bad qualities [2, 179].

Such interchangeable use of the prefixes 向 xiang and 在 zai is not found in modern Chinese putonghua, but it is preserved in the Guangdong dialect. For example, in Guangdong, Where is he is expressed in Putunghua as 他在哪里 Tā zài nălǐ, in Guangdong as 佢向边处 qú xiàng biān chù. Here: 佢 qú is the third person singular, 向 xiàng...in prefixes, 边 biān side; toward, , 处 chù have; available; The meanings of In this case, the prefixes 向 xiang and 在 zai have the same meaning [2, 180].

After the Middle Ages, during the Ming and Qing dynasties, in sources devoted to the analysis of novels written in Baihua, the morpheme 向 xiang was used instead of 对 dui ... to to express the direction of movement; the morphems meaning 和 he ... to the side; 替 ti..to; were used as an prefixes function [10, 231].

Wanyanisms (文言词语) are words derived from the ancient literary Chinese language from the Wenyan language, which are also commonly used in the modern Chinese language, which occur in the form of phraseologies and grammatical constructions.

These Wenyanisms, which are part of the lexical and syntactic system of the Chinese language, retain their meaning in a short and concise manner.

The prefix 于 is used in modern Chinese only in written speech, the prefix 在 signifies the nature of meaning, time and place.

Among the equal connectors used in classical literary monuments, 与 and 及 are now found in journalistic style, newspaper texts, socio-political texts, and are synonymous with the prefixes and connectors of the present such as 跟, 同, 和.

The 若 ruò "the same; supposedly" conjunction is often observed in written monuments of historical content, 如 rú “such as; similar"was more actively used in political texts. 如 rú is used in conditional sentences and is exactly the same as 如果 in putonghua.

The suffix 者 was active in the formation of professional words in modern Chinese, and it was also an independent word in Wenyan that feeds a person.

Many of the words borrowed from Wenyan have not only been preserved in Baihua, but have also been assimilated in the new language situation. For example:

如何 what?, how? and 如 此 so, like that way; or from equal binders 与 and 及; negative adverbs 无 and 非 are active in modern Chinese and are used as 无法 (没有办法), 并非 (并不).

\section{The prefixes 和 hé and 合 hé}

Modern Chinese putunghua, these two prefixes occur in a connecting function. However, if we look at the sources, these two morphemes originally came in the baihua as a pre-auxiliary function and in the Uzbek language expressing the suffix ...to [2, 237].

又闻得沈经历文武全才, 都来合他去射箭。Yòu wén dé chén jīnglì wénwǔ quán cái, dōu lái hé tā qù shèjiàn. Яна Шeнट иш юритувчининг харбий кобилиятга эга бўлганлигини билиб, барчасини унга қарата камон отди. In the sentence combination 合他去射箭 hé tā qù shèjiàn Shot at him with a bow the morpheme 合 hé has been performing the function prefix. According to Chinese linguists who have analyzed ancient Baikhua sources, the morpheme 合 hé was pronounced as ho in the Yuan Dynasty and the Ming Dynasty, and the morpheme 和 he as huo.

Later, the prefix 合 hé was expressed by the hieroglyph 和 hé, and began to be pronounced as hé. In modern Chinese, these two morphemes act as conjunctions, sometimes as verbs [2, 231].

Periodicals of the Wenyan lexicon in Baikhua had a strong influence on journalism. Although newspapers and magazines were published in Baihua, Wenyan elements played an important role in expressing the stable associations and phraseology, the sharpness of the journalistic text, and the coloring of the work of art. Although the baihua has been officially in circulation in China 


\section{The Impact of Ancient Chinese on Baihua Language}

since the second half of the twentieth century, the Wenyan have not yet lost their status as the "upper class - the language of the aristocracy". It was found in the Baihua texts with its charm typical of classical literature. Such venerations appear mainly in political texts in newspapers and magazines, in speeches of statesmen, and in works of art, in the form of 成语 chengyu phraseologies, 固定词语 gùdìng cíyǔ stable associations, and enrich the text with expressiveness.

Chenggyu - 成语 - "ready phrase", ie idioms. Chenggyu is a strong phraseological phrase formed according to the norms of the ancient Chinese language, a semantic unit, a functional part of speech with a generalized figurative meaning. An important part of the phraseological fund of the journalistic style of modern Chinese is the phraseological expressions formed in accordance with the lexical and grammatical norms of the Wenyan language. Such phraseologies consist mainly of four syllables and a morpheme composition [9, 141].

If phraseology is used correctly in journalism, the article will be full of comprehensibility, clarity, naturalness, and thoughtprovoking features. This is sure to ensure the success of these publicist speeches. The same can be said about the reasons why phraseologies have gained public attention and are widely used by the public.

There are also regular expressions that are common in newspaper texts expressed in Wenyan auxiliary words:

此言是也 -cǐ yán shì yě - this is exactly the truth

诚哉此言 - chéng zāi cǐ yán - that is to say

一以贯之 - yīy̆̌guànzhī - in a systematic manner

一言以蔽之曰 - yī yán yǐ bì zhī yuē - in a word

总而言之 - zǒng'éryánzhī - in conclusion from the above, such phraseologies are very common in modern Chinese journalism.

Phraseologisms, according to their stylistic function, are actively involved in speech. Whether a historical classic or a modern writer, they all use phraseology to expand the power of expression in their works. Among modern Chinese writers, such as Mao Dun, Lu Xin, and Lao She, the skillful use of 成语 chengyŭ in their Baihua works made the work more expressive, and the speech more attractive.

\section{CONCLUSION}

From the above, it can be concluded that in 1919, as a result of the "May 4 movement" for the Baihua, the Baihua language was officially introduced. In Baihua, newspapers, magazines and periodicals gradually began to appear. The works of art began to be presented to the general public in Baihua. However, the use of Wenyan elements in journalism and fiction remained relevant. The main reason for this is that the Wenyanisms are short and concise, expressive in expressing thought.

After Baihua gained official status, a comprehensive study of written monuments, fiction created during the Ming and Qing dynasties established in China began. From this period onwards, the direct influence of Western linguistics on the Chinese language became great. A number of reforms in Chinese linguistics, especially in phonetics, writing, and stylistics, were reflected. However, while the Wenyan also influenced the Baihua language with its charm and simplicity, the Baihua, in turn, with its intelligibility and simplicity, laid the foundation for the formation of the modern Chinese Putonghua.

When we think of Baihua lexicon, especially auxiliary word groups, they are also expressed in two syllables as independent word groups, sometimes found in language prefixes expressing a synonymous meaning.

\section{REFERENCES}

1. Mahmutkhadjaev M.X., Turatova M.A. Historical phonology of the Chinese language. Study guide. TDShl, T., 2009.

2. Xiangban Shun, Jiang Lansheng, Bai Weiguo. A study of vernacular vocabulary. Chinese Bookstore. 1997.

3. "Romance of the Three Kingdoms", Chapter 12.

4. https://bkrs.info/

5. Lu Shuxiang. "Outline of Chinese Grammar" Commercial Press. 2013, II.

6. Examples are taken from the novel "Dream of the Red Chamber". The numbers given in parentheses represent the chapters of this novel

7. Zograf I.T. Middle Chinese adverbs. // Written monuments and problems of the history of culture of the peoples of the East. Part 1 (2). Moscow, "Science", 1981.

8. Lu Xun. "home". https://zhidao.baidu.com/

9. Gorelov V.I. The stylistics of the modern Chinese language. M., "Education", 2002.

10. Khasanova, F. (2021). ON THE ISSUE OF THE CHRONOLOGY OF THE HISTORY OF THE BAIHUA LANGUAGE. Oriental renaissance: Innovative, educational, natural and social sciences, 1(Special Issue 1), 200-216. 
The Impact of Ancient Chinese on Baihua Language

11. Khasanova, F. (2020). Introduction of baihua in periodicals. ACADEMICIA: An International Multidisciplinary Research Journal, 10(11), 133-139. 